\title{
SOME THOUGHTS ON THE DYNAMICS OF FEDERAL TRADEMARK LEGISLATION AND THE TRADEMARK DILUTION ACT OF 1995
}

\author{
Robert C. Denicola*
}

\section{INTRODUCTION}

The Lanham Act ${ }^{1}$ is fifty. By some measures at least, it has been an extraordinary success. This essay briefly recounts that success and speculates about its origins. It then worries that the dynamics of federal trademark legislation are changing and that, in the future, such success may be more elusive. The new Trademark Dilution $\mathrm{Act}^{2}$ illustrates the danger.

II

\section{THE FIRST FIFTY YEARS}

\section{A. The Success of the Lanham Act}

Statutes are judged most directly by how well they promote the goals or cure the mischiefs prompting their enactment. This essay leaves to others any such direct assessment of the Lanham Act. Instead, this appraisal of the Act's success rests on circumstantial evidence: the influence of the Act beyond the statute's technical boundaries and its remarkable stability over half a century.

Statutes need not persuade. They are commands from the sovereign to be followed without regard to their wisdom or good sense. However, when appeals are made to a statutory rule in circumstances not technically governed by the statute, the good sense of the legislation is very much at issue. Thus, the enormous influence of Article 2 of the Uniform Commercial Code-technically applicable only to transactions in goods-on the general law of contracts provides convincing evidence of its substantive merit. ${ }^{3}$ The Lanham Act has proven to be similarly persuasive beyond the borders of its jurisdiction.

Copyright $\odot 1996$ by Law and Contemporary Problems

* Margaret Larson Professor of Intellectual Property, University of Nebraska College of Law; Reporter, American Law Institute's Restatement (Third) of Unfair Competition (1995). (1994)).

1. Act of July 5, 1946, ch. 540,60 Stat. 427 (codified as amended at 15 U.S.C. §§ 1051-1127

2. Pub. L. No. 104-98, 109 Stat. 985 (1996).

3. Compare, e.g., U.C.C. $\$ \S 2-302$, -609 (modifying the common law) with RESTATEMENT (SECOND) OF CONTRACTS $\$ \$ 208,251$ (1981) (tracking the U.C.C. rules). 
Federal trademark legislation does not displace state trademark law. Indeed, with some exaggeration, the Lanham Act is often viewed primarily as a vehicle for the federal registration of state-created rights. In trademark infringement actions under state statutes or at common law, the Lanham Act is usually relevant only by analogy. Nevertheless, over the past fifty years, the influence of the Lanham Act on the development of state trademark law has been enormous, at least if we can take the Restatement of Torts (1938) as representative of state trademark law before the implementation of the Lanham Act and the new Restatement (Third) of Unfair Competition (1995) as representative of current law.

The most notable achievement of the Lanham Act may be its role in developing what might be called a unified theory of trademarks-a single set of substantive principles applicable across the spectrum of protectable subject matter. Trademark law originated in the common law action of deceit. Imitation of a trademark by a competitor was viewed as a type of misrepresentation. This particular form of deceit came to be called "unfair competition," and proof of the defendant's fraudulent intent was a crucial element of the cause of action. ${ }^{4}$ When the imitated mark was especially distinctive, such as an invented or arbitrarily chosen symbol of identification, the inference that the defendant's imitation was intended to deceive prospective purchasers evolved into a conclusive presumption of fraud. By the mid-nineteenth century, courts in England and the United States had come to characterize the plaintiff's interest in such a mark as a "property right," and the marks themselves came to be called "trademarks." Complaints of unauthorized trademark use became actions for "trademark infringement."

Less distinctive designations, such as terms describing the qualities of the goods or their geographic origin, can also come to identify for consumers the goods of a particular seller. At common law, these symbols became known as "trade names." Trade names were not technically trademarks, and rights in trade names could not be vindicated through an action for trademark infringement. Sellers complaining of the unauthorized use of trade names were left to the action of unfair competition with its traditional emphasis on a defendant's fraudulent intent. The distinction between trademarks and trade names also carried a variety of other substantive consequences. ${ }^{7}$ Although there had been attempts at a more integrated approach, ${ }^{8}$ the historical bifurcation between trademarks and trade names that had complicated the law

4. RESTATEMENT (THIRD) OF UNFAIR COMPETITION $\S 9 \mathrm{cmt}$. d (1995) [hereinafter UNFAIR COMPETITION RESTATEMENT].

5. See, e.g., Trade-Mark Cases, 100 U.S. 82, 92 (1879).

6. Compare RESTATEMENT OF TORTS $\$ 715(1938)$ [hereinafter TORTS RESTATEMENT] (definition of trademark) with id. $\S 716$ (definition of trade name).

7. The distinctions between "trademarks" and "trade names" were critically reviewed in an influential article by Milton Handler and Charles Pickett, Trade-Marks and Trade Names-An Analysis and Synthesis (pts. 1 \& 2), 30 COLUM. L. REV. 168, 759 (1930).

8. See, e.g., TORTS RESTATEMENT, supra note 6 , $\$ 717 \mathrm{cmt}$. a. 
for a century was still firmly embedded in the common law at the enactment of the Lanham Act.

Packaging and product features also contributed to the fragmentation of the common law. The manner in which goods are packaged or the physical appearance of the goods themselves can sometimes serve as an indication of the source of the product. Although rights in such distinctive "trade dress" could be raised in an action for unfair competition, trade dress was neither a trademark nor a trade name, and protection at common law was governed by yet another collection of substantive rules. ${ }^{9}$

The Lanham Act opted for an integrated approach to trade symbols. The definitions in section 45 of the Act, together with the criteria governing the registration of marks in section 2, swept away the arcane distinctions between trademarks and trade names. Judicial interpretation also brought trade dress and product features within the registration system established by the Lanham Act. ${ }^{10}$ All were now governed by the single standard of infringement in section 32. The impact on state law was dramatic. Within a few years, a Model State Trademark Bill ${ }^{11}$ was prepared on the pattern of the Lanham Act. It quickly became the standard for state trademark legislation. The Lanham Act's approach proved equally persuasive in the courts, and the common law of trademarks gradually abandoned its archaic terminology and the substantive distinctions that it had engendered. ${ }^{12}$ The unified model inaugurated by the Lanham Act is now the standard paradigm of modern trademark law.

The ability to license, another significant development traceable in large measure to the Lanham Act, has added immeasurably to the economic value of modern trademarks. As originally understood, trademarks were symbols indicating the physical origin of goods. This view led many early courts to rule that a trademark owner could not license others to use the mark without destroying its significance as an indication of source; licenses were invalid as a fraud on the public, and licensors risked judicial forfeiture of their trademark rights through a finding of intentional abandonment. ${ }^{13}$ Over time, an alternative view of trademarks (and one more conducive to licensing) made some headway. Trademarks could be understood as indications, not necessarily of physical origin, but of a more general connection between the trademark owner and the trademarked goods. The presence of a trademark can be viewed as an indication of consistency and quality assured through the trademark

\footnotetext{
9. See, e.g., id. $\S \S 741-43$.

10. See UNFAIR COMPETITION RESTATEMENT, supra note $4, \S 16 \mathrm{cmt}$. a \& accompanying reporters' note.

11. Model State Trademark Bill (1949, revised 1964, 1992), reprinted in 3 J. ThOmas MCCARTHY, TRADEMARKS AND UNFAIR COMPETITION $\$ 22.04$ (3d ed. 1995).

12. Compare TORTS RESTATEMENT, supra note $6, \S \S 715-16$ (former common law definitions of trademark and trade name) with UNFAIR COMPETrTION RESTATEMENT, supra note 4, $\$ 9 \mathrm{cmt}$. g, 16 (adopting the Lanham Act definitions).

13. See UNFAIR COMPETITION RESTATEMENT, supra note $4, \S 33 \mathrm{cmt}$. a and accompanying reporters' note.
} 
owner's control over the use of the mark. Thus, a few courts upheld licenses if the trademark owner retained sufficient control to ensure that the marked goods met the expectations created by the appearance of the trademark. ${ }^{14}$ However, at the time of the enactment of the Lanham Act, the question of licensing was still unsettled, ${ }^{15}$ and the resulting uncertainty undoubtedly inhibited the efficient exploitation of trademarks. Through its rule in section 5 that the use of a mark by "related companies" inures to the benefit of the trademark owner, the Lanham Act explicitly authorized the licensing of marks, backed by a definition of "related company" that incorporated the control requirement. The common law quickly adopted a similar position. ${ }^{16}$

Other examples of the Lanham Act's persuasiveness might be listed, including the Act's effect on the common law rules governing the type of use necessary to acquire trademark rights ${ }^{17}$ and its role in refining the concept of trademark abandonment. ${ }^{18}$ Of greater significance is the leading role played by the Lanham Act in the development of the modern law of deceptive marketing. ${ }^{19}$

Durability is another measure of legislative success. The stability of the Lanham Act in the face of changing markets and merchandising strategies has been impressive. The statute has successfully assimilated new advertising media, a marked increased in corporate diversification, the expansion of trademark licensing (including the phenomenon of franchising), and the continuing shift from local to national, and now to international marketing.

During its fifty years, the Lanham Act has been amended some twenty-six times. Most of these bills, however, encompassed only conforming amendments or modest procedural changes. By my count, there have been just eleven

14. See, e.g., E.I. Du Pont De Nemours \& Co. v. Celanese Corp., 167 F.2d 484 (C.C.P.A. 1948); Coca-Cola Co. v. Bennett, 238 F. 513 (8th Cir. 1916).

15. See, e.g., American Broadcasting Co. v. Wahl Co., 121 F.2d 412 (2d Cir. 1941) (questioning the ability to license); Everett O. Fisk \& Co. v. Fisk Teachers' Agency, Inc., 3 F.2d 7 (8th Cir. 1924) (same).

16. See UNFAIR COMPETITION RESTATEMENT, supra note $4, \S 33$. The treatment of trademark law in the Restatement of Torts (1938) did not include a section on trademark licensing.

17. Compare TORTS RESTATEMENT, supra note $6, \S 718$ (trademark must be affixed to the goods) with UNFAIR COMPETITION RESTATEMENT, supra note $4, \S 18 \mathrm{cmt}$. d (abandoning the former rule requiring physical affixation of the mark).

18. Compare TORTS RESTATEMENT, supra note $6, \S 752$ (emphasizing an intent to abandon) with UNFAIR COMPETITION RESTATEMENT, supra note $4, \S 30 \mathrm{cmt}$. b (intent to retain rights will not avoid abandonment).

19. Compare TORTS RESTATEMENT, supra note $6, \S 761 \mathrm{cmt}$. a (requiring proof of a direct diversion of sales from the plaintiff) with post-Lanham Act formulations such as the UNIFORM DECEPTIVE TRADE PRACTiCes ACT § 3(a), 7A U.L.A. 265, 289-90 (1996) (adopting a "likely to be damaged" standard). In some states, competitors can also pursue deceptive marketing claims under the Unfair Trade Practices and Consumer Protection Act (1970). COUNCIL OF STATE GOVERNMENTS, 26 SUGGESTED STATE LEGISLATION 141 (1970); see UNFAIR COMPETITION RESTATEMENT, supra note 4, $\$ 1$ statutory note. The common law rules on deceptive marketing may now also coincide with those in $\S 43$ (a) of the Lanham Act. 19. See id. $\$ 2 \mathrm{cmt}$. b. As a result of the 1988 revision of the Lanham Act that brought disparagement of another's product within the scope of the deceptive marketing rules in $\S 43(\mathrm{a})$, common law liability for product disparagement may be the next area to respond to statutory innovations in the Lanham Act. See id. cmt. c. 
substantive amendments to the Act. ${ }^{20}$ Only one, the Trademark Revision Act of 1988 , might be judged a major revision. ${ }^{21}$ Although relatively modest in scope, the second most comprehensive amendment (and the only one to tinker with the general standard of infringement) dates back to $1962 .{ }^{22}$ This stability can be contrasted with the tumultuous history of the federal copyright statute. Since the enactment of a thorough-going revision in $1976,{ }^{23}$ the Copyright Act has endured almost twice as many substantive amendments in its twenty years as the Lanham Act has experienced in a half-century.

\section{B. Origins of Success}

Why has the Lanham Act succeeded? In contrast to copyright, its success is surely attributable in some measure to trademark's relative immunity from the stresses generated by new technologies. However, there may be a deeper reason: The Lanham Act, despite its innovations, is in essence a codification. The Lanham Act has embraced the balance of interests drawn over more than a century of common law adjudication. The common law rules defining a protectable mark as well as the common law's concept of infringement and the trademark rights that the concept delineates are all preserved in the federal legislation. Putting aside statutory innovations directly linked to the public notice provided by the Act's registration system, ${ }^{24}$ the Lanham Act codifies the

20. I count the following: (1) Act of Oct. 3, 1961, Pub. L. No. 87-333, 75 Stat. 748 (effect of applications for foreign registration); (2) Act of Oct. 9, 1962, Pub. L. No. 87-772, 76 Stat. 769 (modifying, inter alia, the standard of confusion governing registration and infringement); (3) Act of Jan. 2, 1975, Pub. L. No. 93-600, 88 Stat. 1955 (awards of attorneys fees); (4) Trademark Counterfeiting Act of 1984, Pub. L. No. 98-473, $\$$ 1501-03, 98 Stat. 2179, $2179-83$ (remedies for trademark counterfeiting); (5) Trademark Clarification Act of 1984, Pub. L. No. 98-620, \$§ 101-04, 98 Stat. 3335, $3335-36$ (determination of generic status); (6) Trademark Revision Act of 1988, Pub. L. No. 100-667, 102 Stat. 3935 (including intent to use provisions and amendments to $\S 43(\mathrm{a})$ ); (7) Trademark Remedy Clarification Act of 1992, Pub. L. No. 102-542, 106 Stat. 3568 (liability of states for infringement); (8) NAFTA Implementation Act of 1993, Pub. L. No. 103-182, 107 Stat. 2114 (restrictions on registration of certain geographic designations); (9) Uruguay Round Agreements Act of 1994, Pub. L. No. 103-465, 108 Stat. 4981 (geographic indications on wines and spirits and presumption of abandonment); (10) Federal Trademark Dilution Act of 1995, Pub. L. No. 104-98, 109 Stat. 985 (protection against dilution of distinctiveness); and (11) Anticounterfeiting Consumer Protection Act of 1996, Pub. L. No. 104-153, 110 Stat. 1386 (enhancing remedies against counterfeiters).

21. Pub. L. No. 100-667, 102 Stat. 3935 (1988).

22. Pub. L. No. 87-772, 76 Stat. 773 (1962) (eliminating the former requirement in $\S 32(1)$ that confusion "deceive purchasers as to the source of origin" of the goods or services).

23. Even as originally enacted, the Copyright Act of 1976, Pub. L. No. 94-553, 90 Stat. 2541, was nearly three times as long as the 1909 Act that it replaced. It is now approaching six times the length of its predecessor.

24. Until the recent dilution amendment, most of the Lanham Act's major substantive innovations could be rationalized as outgrowths of the public notice afforded by the Act's registration system. Thus, the geographic expansion of trademark rights beyond the user's actual market through the concept of constructive notice reflected in 15 U.S.C.A. $\$ 1072$ and the loss of specified defenses not raised in time to prevent an owner's rights from being "incontestable" in 15 U.S.C.A. $\$ \S 1065$ and 1115 (b) can both be justified on the basis of an accessible public record of the trademark owner's claim. The ability since the 1988 revision to establish rights prior to actual use of the mark through an intent-to-use application can be justified on the same basis. See 15 U.S.C.A. $\$ \S 1051(b), 1057$ (c) (West Supp. 1996); 3 MCCARTHY, supra note $11, \S 26.15$, at $26-58$ to -59 . 
basic common law principles governing both the subject matter and scope of protection. That may be the Lanham Act's fundamental strength, since there are reasons to believe that, in the long run, courts will make better trademark law than legislatures.

To be successful, trademark law must respond effectively to complex and sometimes inconsistent interests. Protection against infringement reduces the cost to consumers of acquiring reliable information about the source of a product and, hence, about its anticipated characteristics and quality. Protection also encourages investment in good will by ensuring trademark owners the opportunity to capture the rewards of a favorable reputation. But trademark law must also be responsive to the public interest in competition. Excessive protection can inhibit the communication of useful information by other sellers in the marketplace, and rights in packaging and product features can deprive competitors of access to elements crucial to effective competition. As trade symbols enter the general vocabulary, the law must also take account of the constitutional protection afforded noncommercial speech. These latter interests-the interests weighing against protection-are more likely to be represented effectively in common law adjudication than in the legislative process.

In trademark litigation, one party or the other will typically find it expedient to cloak itself tightly in the public interest. However, an adversarial process forces attention on pros and cons of such interests. The judiciary may systematically err in one direction or another, but usually not for lack of exposure to the real or imagined interests at issue.

The legislative process is more problematic. Owners of well-known trademarks are generally well-off and well-organized. They are important constituents in every political district, and their lobbying capabilities are impressive. Their chief trade organization, the United States (now International) Trademark Association, was single-handedly responsible for the 1988 Trademark Revision Act. On the other hand, small market entrants looking for a leg up, manufacturers specializing in knock-offs, supermarket shoppers, and parodists (let alone t-shirt bootleggers) are not, as a general matter, well represented in the legislative process. ${ }^{25}$ At best, they are left in the unenviable position of relying on testimony by public-spirited academic economists, or even

An obvious exception is the liability created under $\S 43$ (a) for deceptive advertising. This legislative expansion of common law liability may be more easily defended than those relating to trademark rights. See infra note 27.

25. Commenting at a Senate hearing on the 1988 Revision Bill, Beverly W. Pattishall, well-known trademark attorney and long-time supporter of dilution protection, see Beverly W. Pattishall, The Dilution Rationale for Trademark-Trade Identity Protection, Its Progress and Prospects, 71 NW. U. L. REV. 618 (1976); Beverly W. Pattishall, Dawning Acceptance of the Dilution Rationale for TrademarkTrade Identity Protection, 74 TRADEMARK REP. 289 (1984), opined, "I can't think of any group that would do anything but either ignore it or endorse it." 35 PAT. TRADEMARK \& COPYRIGHT J. (BNA) 403, 405 (1988). The organized media sometimes accounts for an exception to the general underrepresentation of the anti-protectionist position, but its interests are usually too narrow to provide comprehensive balance. 
law professors. ${ }^{26}$ This imbalance is troubling, whether we view the legislative process as a rational balancing of interests in furtherance of the general welfare or as a market in legislation. ${ }^{27}$ From this perspective, a legislative strategy built on the codification of common law trademark principles is appealing-an intuition that the Lanham Act has generally heeded for fifty years. Unfortunately, this welcome conservatism, overwhelmed by an increasing fixation on international markets, may be ending.

Attention to the international dimension of intellectual property law is altogether prudent, to a point. For trademarks, the Paris Convention has long been the principal international treaty. Members, including the United States, promise national treatment for citizens of other member states and also agree to maintain at least a specified minimum level of trademark protection. More recently, there have been moves to harmonize trademark registration procedures (the Trademark Law Treaty) and to create a central application system for foreign registrations (the Madrid Protocol). ${ }^{28}$ In addition, the recent NAFTA and GATT trade agreements both produced modest changes to the federal trademark statute. ${ }^{29}$ The difficulty lies, however, not so much in statutory amendments implementing formal treaty obligations, but in impassioned pleas for ever-increasing protection rationalized by assertions about foreign revenues and trade balances.

26. Ralph Brown of the Yale Law School, my co-author in copyright (see infra note 35), was one of the few persons to testify in opposition to portions of the 1988 Trademark Revision Act. See 36 PAT. TRADEMARK \& COPYRIGHT J. (BNA) 489, 490 (1988).

27. On the latter view, see Frank H. Easterbrook, The Supreme Court 1983 Term-Foreword: The Court and the Economic System, 98 HARv. L. REV. 4 (1984); William M. Landes \& Richard A. Posner, The Independent Judiciary in an Interest-Group Perspective, 18 J. L. \& ECON. 875 (1975).

Copyright revision may reflect yet another model of the legislative process. Unlike trademarks, both owners and users of copyrighted subject matter are well organized. Much of the 1976 Copyright Act and its subsequent amendments were drafted, not by legislators or their staffs, but by affected interest groups during protracted negotiations. Jessica D. Litman, Copyright, Compromise, and Legislative History, 72 CORNELL L. REV. 857 (1987). Groups not at the table were frequently shortchanged. See Jessica Litman, Copyright Legislation and Technological Change, 68 OR. L. REV. 275 (1989).

Consideration of deceptive advertising issues under the Lanham Act is not hobbled by the imbalance in representation that plagues trademark issues. Large companies can as easily find themselves on one side of advertising complaints as on the other, and here the media is also a consistent player in the legislative process.

28. Neither treaty has been ratified by the United States. See generally Jeffrey M. Samuels \& Linda B. Samuels, The Changing Landscape of International Trademark Law, 27 GEO. WASH. J. INT'L L. \& ECON. 433 (1993-94); Roger E. Schechter, Facilitating Trademark Registration Abroad: The Implications of U.S. Ratification of the Madrid Protocol, 25 GEO. WASH. J. INT'L L. \& ECON. 419 (1991).

29. See Uruguay Round Agreements Act of 1994, Pub. L. No. 103-465, 108 Stat. 4981 (geographic indications on wines and spirits; presumption of abandonment); NAFTA Implementation Act of 1993, Pub. L. No. 103-182, 107 Stat. 2114 (registration of geographic designations). Cf. Peter M. Brody, Protection of Geographical Indications in the Wake of TRIPs: Existing United States Laws and the Administration's Proposed Legislation, 84 TRADEMARK REP. 520 (1994) (arguing that additional changes relating to geographic designations may be necessary to comply with the Uruguay Agreement); Elke E. Werner, Comment, Are We Trading Our Lanham Act Away? An Evaluation of Conflicting Provisions Between the NAFTA and North American Trademark Law, 2 Sw. J.L. \& TRADE AM. 227 (1995) (arguing that further changes in American trademark law are necessary to conform to NAFTA). 
There are trade-based arguments for increased domestic intellectual property protection suitable for every occasion. When the level of intellectual property protection in a foreign country is higher than in the United States, American works marketed in that country are sometimes limited on a reciprocity rationale to the lower level of protection available here. Thus, the argument is straightforward: Raise the level of protection for works at home, and Americans will suddenly earn billions more through expanded rights abroad.

The current push to extend the term of copyright protection from an already handsome life-of-the-author plus fifty years to life plus seventy years epitomizes the prevailing logic. In order to harmonize the term of copyright within the European Union, the Union issued a directive for a life-plus-seventy-year term to match the German law, which had the longest copyright term in Europe. Protection of American works sold in Europe, however, would still be limited by our own life-plus-fifty term. The argument for extension was clear: How can we afford to pass up twenty additional years of foreign royalties on American songs, books, and movies? $?^{30}$ Opponents of the extension have been forced to rely on law professors to make the point that increased protection has costs as well as benefits. ${ }^{31}$ A similar argument based on lost economic opportunities in foreign markets has been made to support the push for a public performance right in sound recordings. ${ }^{32}$ The recently passed amendment to the Copyright Act creating a narrow performance right for digital transmissions of sound recordings ${ }^{33}$ is unlikely to win performance protection for U.S. recordings abroad; thus, the pressure for increased domestic protection will undoubtedly continue. Acknowledging the political opposition to wider protection, the Commissioner of Patents and Trademarks raised the trade argument to its ultimate plane by suggesting that, in order to obtain increased

30. "If the Congress does not extend to Americans the same copyright protection afforded their counterparts in Europe, American creators will have 20 years less protection than their European counterparts-20 years during which Europeans will not be paying Americans for their copyrighted works." 141 Cong. Rec. E379 (daily ed. Feb. 16, 1995) (statement of Rep. Moorhead). At a Senate hearing on the proposed extension, Commissioner of Patents and Trademarks Bruce Lehman lamented that the disparity between U.S. and foreign copyright terms "leaves a lot of money on the table." 50 PAT. TRADEMARK \& COPYRIGHT J. (BNA) 589, 590 (1995). The most interesting response to the extension issue came from Senator Dodd, who proposed auctioning off the 20 years of added protection, with the proceeds going to the National Endowments for the Arts and the Humanities. 140 Cong. Rec. S12619 (daily ed. Aug. 25, 1994).

31. Professor Peter Jaszi of American University was the only witness to testify in opposition to the extension bill at a hearing before the Senate Judiciary Committee. 50 PAT. TRADEMARK \& Copyright J. (BNA) 589, 591 (1995). Professor Dennis Karjala of Arizona State carried the burden of opposition before the House Subcommittee on Courts and Intellectual Property. Id. at 282, 283.

32. "Due to the lack of a performance right in the United States, U.S. performers and record companies are denied their fair share of foreign royalty pools for the public performance of U.S. sound recordings in some countries and are in danger of losing access to their share in others." Working Group on Intellectual Property Rights, Information Infrastructure Task Force, Intellectual Property and the National Information Infrastructure 222-23 (1995).

33. Digital Performance Right in Sound Recordings Act of 1995, Pub. L. No. 104-39, 109 Stat. 336. The amendment covers only certain digital audio transmissions. 
protection for sound recordings under domestic law, "we may have to negotiate a treaty that requires those changes in U.S. law."34

Perhaps surprisingly, trade-based arguments are popular even when the domestic law of the United States provides the same or greater protection than foreign law. Enactment of increased domestic protection, it is said, shows our good faith and strengthens the hand of our negotiators pressing for greater protection of American works abroad. This holier-than-thou attitude seems nothing short of miraculous to those who remember the American position prior to the 1980s. For decades, the United States showed little embarrassment in preaching the virtues of strong intellectual property protection abroad while lingering with the sinners outside the Berne Convention, which serves as the chief international agreement on copyright. ${ }^{35}$

Regardless of the relative levels of domestic and foreign protection, the lure of increased revenues from abroad creates unremitting pressure to expand the scope of intellectual property protection at home. The Lanham Act is not immune to these arguments. They may well have tipped the balance in the case of the recent dilution amendment.

\section{III}

\section{The Trademark Dilution ACt}

\section{A. Dilution Theory}

On January 16, 1996, President Clinton signed the Federal Trademark Dilution Act. ${ }^{36}$ Similar legislation had failed several years before when proposed as part of the Trademark Revision Act of 1988. The earlier failure was attributable in part to the opposition of Congressman Robert Kastenmeier, then chair of the House subcommittee that considered the 1988 bill. $^{37}$ However, in addition to the departure of Congressman Kastenmeier, another major change was evident when the dilution issue resurfaced in 1995. Arguments relating to trademark protection in foreign markets, noticeably absent during consideration of this aspect of the 1988 bill, appeared now at every stage of the legislative process. At a House hearing, the Administration supported the dilution bill on foreign trade grounds and opposed a provision limiting the bill to federally registered marks by arguing that the limitation

34. 50 PAT. TRADEMARK \& COPYRIGHT J. (BNA) 244, 245 (1995) (testimony of Bruce Lehman before the House Subcommittee on Courts and Intellectual Property).

35. Even when the United States did join Berne in 1988, we adopted a "minimalist" approach with respect to our obligations under the Convention. RALPH S. BROWN \& ROBERT C. DENICOLA, CASES ON COPYRIGHT 709 (6th ed. 1995).

36. Pub. L. No. 104-98, 109 Stat. 985 (1996).

37. See Jerome Gilson, A Federal Dilution Statute: Is It Time?, 83 TrademaRK ReP. 108, 114 (1993). 
"clearly undercuts the United States'[s] position with its trading partners." 38 On the floor of the House, Congresswoman Pat Schroeder argued that a more limited bill "is not within the spirit of the United States position as a leader setting the standards for strong worldwide protection of intellectual property." ${ }^{39}$ In the Senate, Senator Orrin Hatch said that the bill would "assist the executive branch in its bilateral and multilateral negotiations with other countries to secure greater protection for the famous marks owned by U.S. companies." ${ }^{\text {"40 }}$ Senator Patrick Leahy spoke of "strengthen[ing] the hand of our international negotiators." 41

The Lanham Act in new subsection 43(c) now protects the owner of a "famous" mark from a commercial use that "causes dilution of the distinctive quality of the famous mark." ${ }^{22}$ "Dilution" is in turn defined as "the lessening of the capacity of a famous mark to identify and distinguish goods or services," without regard to the presence of competition between the users or the likelihood of confusion among consumers. ${ }^{43}$ Unlike the traditional likelihood of confusion standard, the concept of "dilution" is not a product of the common law. It is borrowed instead from statutory formulations found in about half of the states.

38. 50 Pat. TRADEMARK \& Copyright J. (BNA) 325 (1995) (testimony of Commissioner of Trademarks Philip Hampton before the House Subcommittee on Courts and Intellectual Property). The limitation was eventually dropped. Id. at 344-45.

39. 141 Cong. Rec. H14318 (daily ed. Dec. 12, 1995). The inclusion of unregistered marks undercuts any attempt to link the dilution amendment to the public notice function of the federal statute. See supra note 24.

40. 141 Cong. Rec. $\$ 19310$ (daily ed. Dec. 29, 1995). Senator Hatch also made a more direct appeal to international considerations in support of the bill, arguing that "the GATT agreement includes a provision designed to provide dilution protection to famous marks." Id. The provision in question is Article 16(3) of the Agreement on Trade Related Aspects of Intellectual Property Rights ("TRIPS"), a component of the GATT Uruguay Round. Article 16(3) extends the protection against imitations of well-known marks on identical or similar goods contained in Article 6 bis of the Paris Convention to use on dissimilar goods or services if the use "would indicate a connection between those goods or services and the owner of the registered trademark and provided that the interests of the owner of the registered trademark are likely to be damaged by such use." Agreement on Trade-Related Aspects of Intellectual Property Rights, Apr. 15, 1994, Marrakesh Agreement Establishing the World Trade Organization, Annex 1C, LEGAL INSTRUMENTS-RESULTS OF THE URUGUAY ROUND vol. 31; 33 I.L.M. $81,89-90$ (1994). It is not at all clear that this provision requires enactment of a federal dilution statute. See Jerome H. Reichman, Universal Minimum Standards of Intellectual Property Protection under the TRIPS Component of the WTO Agreement, 29 INT'L LAW. 345, 363 (1995). The protection afforded under American statutory and common law against uses on noncompeting goods that are likely to cause confusion as to sponsorship, approval, or other association, see UNFAIR COMPETITION RESTATEMENT, supra note $4, \S \S 20 \mathrm{cmt}$. d, $21 \mathrm{cmt}$. j, might itself be sufficient to satisfy our treaty responsibilities, especially in light of the minimalist position often adopted by the U.S. with respect to its obligations under intellectual property conventions. See supra note 35 . In addition, half of the states already have dilution statutes, and this existing legislation might be sufficient under TRIPS. Reliance on state law was used to justify the absence of a federal moral rights statute at the time of our adherence to the Berne Convention. See BROWN \& DENICOLA, supra note 35, at 709. Further, the federal dilution amendment was not included as part of the Uruguay Round Agreements Act of 1994, Pub. L. No. 103465, 108 Stat. 4981, which made only two minor changes to the Lanham Act. See supra note 20.

41. 141 Cong. Rec. S19312 (daily ed. Dec. 29, 1995).

42. 15 U.S.C.A. $\$ 1125$ (c) (West Supp. 1996).

43. Id. $\$ 1127$ (West Supp. 1996). 
Frustrated by the reluctance of courts and legislatures in the early decades of the century to extend liability for trademark infringement to uses on noncompeting goods, some commentators, most notably Frank Schechter ${ }^{44}$ urged a new rationale for protection. The primary value of a trade symbol was seen as its power to generate sales, and that value should be protected against the "gradual whittling away or dispersion of the identity and hold upon the public mind by its use upon non-competing goods." 45 Only a few decisions actually acknowledged this interest, ${ }^{46}$ and subsequent case law and legislation, including the Lanham Act, reflected a more modest expansion of protection against use on non-competing goods through an extension of the confusion rationale. However, beginning in 1947 with Massachusetts, a number of states enacted statutes directly adopting the dilution rationale. ${ }^{47}$

State dilution acts have been invoked against two distinct threats to the value of a trademark. For marks that are highly distinctive (or "famous" according to subsection $43(\mathrm{c})$ ), use by another to identify different goods or services undermines or blurs the association between the symbol and the former user. Protection against this dilution of distinctiveness is the central theme of the state statutes. ${ }^{48}$ However, the value of a trademark can also be reduced by a use that "tarnishes" the image of the symbol or disparages the mark or its owner. Thus, dilution statutes also have been invoked to enjoin uses found to burden the symbol with negative associations that lessen its value to the original user. $^{49}$

Protection against the dilution of a mark's distinctiveness is self-limiting. Only unauthorized use of a mark to identify the goods or services of someone other than the trademark owner will blur the association between the symbol and the initial user. Use of the mark instead to refer back to the trademark owner or its products serves only to confirm rather than undermine the existing associational significance of the symbol. Thus, the dilution of distinctiveness rationale encompasses only unauthorized use as a trademark.

The tarnishment rationale, however, is not similarly limited. The positive image enjoyed by a mark can, of course, be tarnished by unauthorized use as a trademark on inferior or inappropriate products. But the image can also be

44. See Frank I. Schechter, The Rational Basis of Trademark Protection, 40 HARV. L. REV. 813 (1927).

45. Id. at 825. Modern economic analysis has not been supportive of the dilution rationale. See, e.g., William M. Landes \& Richard A. Posner, Trademark Law: An Economic Perspective, 30 J. L. \& ECON. 265, 306-09 (1987); William P. Kratzke, Normative Economic Analysis of Trademark Law, 21 MEMPHIS ST. U. L. REV. 199, 284-86 (1991).

46. See, e.g., Bulova Watch Co. v. Stolzberg, 69 F. Supp. 543 (D. Mass. 1947); Alfred Dunhill of London, Inc. v. Dunhill Shirt Shop, Inc., 3 F. Supp. 487 (S.D.N.Y. 1929).

47. At current count, dilution statutes have been enacted in 27 states. See UNFAIR COMPETITION RESTATEMENT, supra note $4, \S 25$ statutory note, with the addition of Minnesota, MiNN. STAT. § 325D.165 (1995), and South Carolina, S.C. CODE ANN. § 39-15-1165 (Law. Co-op 1996).

48. For a useful analysis of this branch of the state dilution statutes, see Mead Data Cent., Inc. v. Toyota Motor Sales, Inc., 875 F.2d 1026 (2d Cir. 1989).

49. The state statutes typically encompass a "likelihood of injury to business reputation." See MODEL STATE TRADEMARK BILL \& 12 (1964). 
tarnished when the mark is used to refer back to the trademark owner in the course of commentary, criticism, or parody directed at the owner, at the owner's products, or at the mark itself. However, any application of the dilution rationale to provide relief from harm to the value of a trademark inflicted by unwelcome speech, whether commercial or noncommercial, raises substantial constitutional and public policy issues.

Two recent cases, one noncommercial, the other involving a competitor, illustrate the problem. In Anheuser-Busch, Inc. v. Balducci Publications, ${ }^{50}$ the publisher of a humor magazine ran afoul of Missouri's dilution statute when, using a number of Anheuser-Busch trademarks, it published a parody advertisement for a product called Michelob Oily. The advertisement, with various references to oil pollution, ran soon after the occurrence of an oil spill in the Gasconade River, a water supply for Anheuser-Busch, which apparently forced the temporary closing of the company's St. Louis brewery. Relying on the tarnishment rationale, the Court of Appeals for the Eighth Circuit said that the trademarks were injured by "a negative, although vague, statement about the quality of the product represented by the trademark." 51 The court rejected a first amendment defense.

In Deere \& Co. v. MTD Products, Inc., ${ }^{52}$ the Court of Appeals for the Second Circuit affirmed a preliminary injunction issued under the New York dilution statute against a competing manufacturer of lawn tractors that had the temerity to poke fun at Deere's leaping deer logo. In a comparative advertisement intended to inform consumers that its tractors were just as good as a Deere but less costly, the defendant animated the Deere logo and chased it from the scene with one of its own Yard-Man tractors, assisted by a barking dog recognizable, as the district court found, "as a breed that is short in stature." 53 Although indicating that "[s]atirists, selling no product other than the publication that contains their expression" have wider latitude (and, more grudgingly, that sellers of non-competing products probably do too), ${ }^{54}$ the court said that the degree and nature of the alterations made to the plaintiff's trademark by a direct competitor went too far. The court appeared largely unconcerned with the truth or falsity or even the content of the message that the advertisement actually conveyed to consumers.

The proper interpretation of state dilution statutes was among the more contentious issues addressed during the drafting of the American Law Institute's ("ALI's") new Restatement (Third) of Unfair Competition (1995). When the

50. 28 F.3d 769 (8th Cir. 1994), cert. denied, 115 S. Ct. 903 (1995).

51. Id. at 777 . Although only $6 \%$ of the respondents in a survey conducted for the plaintiff believed the parody to be an actual Anheuser-Busch advertisement, the court also found a likelihood of confusion, relying primarily on survey evidence that $58 \%$ believed that the creator of the ad would need permission to use the Michelob name. Id. at 772-73. The latter evidence, however, does not unambiguously establish a likelihood of confusion.

52. 41 F.3d 39 (2d Cir. 1994).

53. Id. at 41.

54. Id. at 44-45. 
advisers took up the reporters' preliminary draft of section 25 of the Restatement ("Liability Without Proof of Confusion: Dilution and Tarnishment"), there were sharp differences on the merits. The academic members ${ }^{55}$ were generally opposed to the whole notion of dilution protection while the trademark practitioners ${ }^{56}$ generally supported it. $^{57}$ The overall tenor of the discussion was accurately captured by Geoffrey Hazard, director of the ALI, when he later told a meeting of the Council of the ALI that all of the advisers recognize that state dilution statutes exist, but most of them wish they did not. ${ }^{58}$

As ultimately promulgated by the ALI, the section on dilution limits the statutory cause of action to uses that are likely to create an association between the mark and the goods or services of the new user. On the other hand, use of another's mark, not as a trademark to identify the new user's own products, but to refer back to the original trademark owner, is not included within the scope of the dilution rationale. Thus, under section 25(2), the use of another's mark "not in a manner that is likely to associate the other's mark with the goods, services, or business of the actor, but rather to comment on, criticize, ridicule, parody, or disparage the other or the other's goods, services, business, or mark" is outside the reach of the dilution action. Under the Restatement, relief for harm resulting from such "nontrademark" use must be sought through causes of action governing liability for injurious speech such as defamation or disparagement, with their well-developed accommodation of free speech rights. $^{59}$

\section{B. Dilution Under the Lanham Act}

How large a dose of anti-dilution does the Lanham Act's new amendment dispense? One thing is clear. Under the amendment's definition of "dilution," our corner of the world is now safe from DuPont shoes, Buick aspirin, and Kodak pianos. ${ }^{60}$ If it is true that the only thing worse than a bad law is a bad

55. The academic members were led primarily by Ralph Brown of the Yale Law School and David Lange of the Duke University School of Law, and included Milton Handler, long associated with the Columbia University School of Law.

56. The trademark practitioners included Miles Alexander of Atlanta, William Borchard of New York, and Jerome Gilson of Chicago.

57. Personal notes from the meeting of the advisers on the Restatement (Third) of Unfair Competition (Oct. 27-28, 1989). See also the comments by then-Chief Judge Helen Nies of the Federal Circuit, also an adviser: "At a drafting session on the Restatement of Law of Unfair Competition, the proposed section on dilution was reached. The trademark lawyers were generally the advocates of recognizing a broadly worded cause of action." Helen W. Nies, The Lanham Act-Looking at an Old Friend From a New Perspective, 82 TRADEMARK REP. 793, 797 (1992). The International Trademark Association also argued in favor of a broad dilution section. Letter from Richard M. Berman, President, INTA, to Geoffrey Hazard, Director, ALI (Sept. 3, 1993).

58. Personal notes from the meeting of the Council of the ALI (Dec. 6, 1989).

59. UNFAIR COMPETITION RESTATEMENT, supra note 4 , $\$ 25 \mathrm{cmt}$. i.

60. "Thus, for example, the use of DuPont shoes, Buick aspirin, and Kodak pianos would be actionable under this bill." 141 Cong. Rec. S19310 (daily ed. Dec. 29, 1995) (statement of Sen. Hatch); accord 141 Cong. Rec. H14317 (daily ed. Dec. 12, 1995) (statement of Rep. Moorhead). 
law applicable in only half of the states,${ }^{61}$ perhaps the federal amendment will pass as progress. But what about other kinds of uses-the "nontrademark" uses that the Restatement tries to read out of state dilution law?

Proponents of the federal legislation, perhaps relying on rhetoric left over from consideration of the proposal's previous incarnation in the 1988 revision, tell us that the amendment extends protection beyond unauthorized use as a trademark. In identical language, the House and Senate sponsors informed their chambers that the bill would protect famous marks from uses "that blur the distinctiveness of the mark or tarnish or disparage it." ${ }^{\prime 62}$ The analysis accompanying the bill on its introduction in the Senate states that the definition of dilution "is designed to encompass all forms of dilution recognized by the courts, including disparagement." 63 However, analysis of both the genealogy of the amendment and its plain meaning indicates that these descriptions are probably wrong. The amendment is (and should be) limited to DuPont shoes-to a loss of distinctiveness occasioned by a subsequent use of the mark as a trademark to identify another's goods or services.

1. Genealogy. When Senator Hatch introduced the dilution bill late in 1995, he assured his colleagues that the proposal "eliminates any concerns previously voiced in congressional hearings regarding the former [f]ederal dilution provision." 64 The prior proposal had been stripped from the Trademark Revision Act $^{65}$ before the Act's passage in 1988. Like the rest of the Revision Act, the 1988 provisions on dilution and tarnishment had been taken from the Report and Recommendations on the United States Trademark System and the Lanham Act, a study prepared by the Trademark Review Commission ("TRC"), a private committee established by the United States Trademark Association. ${ }^{66}$ As in the 1995 amendment, both the TRC Report and the 1988 revision bill proposed a new subsection 43(c) that would protect against "dilution of the distinctive quality" of a famous mark. ${ }^{67}$ There was also a proposed definition of "dilution" generally similar to the one included in the

61. See Richard A. De Sevo, Antidilution Laws: The Unresolved Dilemma of Preemption Under the Lanham Act, 84 TRADEMARK REP. 300, 324 (1994).

62. 141 Cong. Rec. $\$ 19310$ (daily ed. Dec. 29, 1995) (statement of Sen. Hatch) (emphasis added); 141 Cong. Rec. H14317 (daily ed. Dec. 12, 1995) (statement of Rep. Moorhead) (same).

63. 141 Cong. Rec. S19311 (daily ed. Dec. 29, 1995). In a Special Report announcing passage of the Act, the International Trademark Association, a major proponent, stated that the new law protects against

either the blurring of a trademark's product identification or the tarnishment of the affirmative associations a trademark comes to convey .... "Tarnishment" arises when a famous trademark is linked to products of shoddy quality or portrayed in an unwholesome or unsavory context likely to evoke unflattering beliefs about the owner or its products.

INTA Special Report 1 (Jan. 1996) (emphasis added).

64. 141 Cong. Rec. S19310 (daily ed. Dec. 29, 1995) (statement of Sen. Hatch).

65. Pub. L. No. 100-667, 102 Stat. 3935.

66. The Report is reprinted in 77 TRADEMARK REP. 375 (1987).

67. S. 1883,100 th Cong. $§ 29$ (1987); The United States Trademark Association, Trademark Review Commission, Report and Recommendations to USTA President and Board of Directors, 77 TRADEMARK REP 375, 458 (1987) [hereinafter TRC Report] 
1995 legislation. ${ }^{68}$ But the TRC Report and the 1988 bill included something else-a proposed amendment to subsection 43(a) that would prohibit the use of a mark or other conduct "likely to disparage or tarnish the mark of another."

Separation of the tarnishment and dilution of distinctiveness theories was not an accident. The TRC Report, commenting on uses that "ridicule, parody, insult, or defame" a mark, noted that the injury is "less dilution than injury to reputation" and that dilution law often does not "fit conceptually.", A separate amendment on tarnishment and disparagement would allow courts to grant relief "in the absence of true dilution." Later, commenting on its proposal for dilution protection in subsection $43(\mathrm{c})$, the TRC reaffirmed the distinction: "The Commission believes that trademark tarnishment and disparagement are a separate form of legal wrong, and recommends amending Section 43(a) to deal with them."

Both the tarnishment and dilution proposals in the 1988 bill failed. Jerome Gilson, who served as the reporter for the TRC and who also testified before Congress in favor of the dilution provision, offered this account: "Unfortunately, in the Senate bill dilution was closely linked to proposals to make trademark disparagement and tarnishment actionable, proposals almost guaranteed to draw First Amendment fire in Congress. The broadcast industry and the media rallied around Representative Robert Kastenmeier and his opposition to these proposals, including dilution protection." "73 Gilson lamented the demise of the dilution portion of the bill, emphasizing that it "was never intended to prohibit or threaten nondenominative or noncommercial expression."

Looking back on the 1988 failure, Gilson argued that any new attempt at dilution legislation should be limited to "trademark-like forms of commercial speech." 75 A statute narrowly tailored to "a diluting trademark on a product, serving as an indication of source," he believed, would avoid the objections that had scuttled the prior bill. ${ }^{76}$ The case for narrowing the dilution proposal was strengthened in 1994 when the Section on Intellectual Property Law of the American Bar Association adopted a resolution favoring passage of a federal dilution statute but opposing passage of a statute "specifically relating to antitarnishment of a trademark." "77 Arguing that "the blurring aspect of dilution should be addressed separately from the tarnishing aspect," the Section concluded that "federal legislation on dilution specifically addressing tarnish-

68. S. 1883 , 100th Cong. $\S 31$ (1987); TRC Report, supra note 67 , at 459 .

69. S. 1883 , 100th Cong. $\$ 28$ (1987); TRC Report, supra note 67 , at 435 .

70. TRC Report, supra note 67, at 433-34.

71. Id at 434 .

72. Id. at 455 n. 134 .

73. Gilson, supra note 37 , at 114 (citations omitted).

74. Id. (emphasis added).

75. Id. at 120. The focus on unauthorized trademark-like uses encompasses the most significant threats to the value of a mark, since unlike most non-trademark uses, trademark uses typically entail continuing, long-term use.

76. Id. at 120-21.

77. Intellectual Property Section, A.B.A., 1994 AnNual Report 49 (1995). 
ment does not seem advisable or realistic." ${ }^{78}$ Separation of blurring and tarnishment issues is also consistent with the increased concentration on foreign trade. Our obligations under the TRIPS Agreement signed as part of the GATT negotiations extend at most to protection against unauthorized use of a mark as a trademark. ${ }^{79}$ Tarnishment of American marks abroad unrelated to their use as another's trademark has never been a significant trade issue.

The drafters of the 1995 amendment listened and learned. Their new proposal retained only the dilution of distinctiveness section from the 1988 revision bill. The former provision offering protection against uses "likely to disparage or tarnish" a mark was dropped. The drafters should be held to their statutory language.

2. Plain Meaning. The operative language of the Trademark Dilution Act protects "the owner of a famous mark ... against another person's commercial use in commerce of a mark or trade name, if such use begins after the mark becomes famous and causes dilution of the distinctive quality of the famous mark." 80 Dilution in turn is "the lessening of the capacity of a famous mark to identify and distinguish goods or services." ${ }^{11}$ Only a use of the mark by another as a trademark for that person's own products can lessen the capacity of the mark to identify and distinguish the goods or services of the trademark owner. ${ }^{82}$ Use other than as a trademark for the subsequent user's own products is thus beyond the plain meaning of the statute. Unlike broader state dilution acts with their references to "injury to business reputation" as well as to "dilution of the distinctive quality of a trademark," statute is limited to uses that blur the source significance of the mark. The amendment's restriction to "famous" marks reinforces this interpretation. Courts have generally restricted protection against dilution of distinctiveness under state statutes to "strong" marks, thereby excluding "weak" marks that are in a sense already diluted. ${ }^{84}$ Such a limitation is inapplicable to protection against tarnishment or disparagement, since even weak marks are subject to these latter injuries. ${ }^{85}$

The dilution amendment contains a list of conduct that is not actionable under the act, including "fair use" in "comparative commercial advertising or

78. Id. at 151-52.

79. See supra note 40.

80. 15 U.S.C.A. \& 1125(c)(1) (West Supp. 1996).

81. Id. $\$ 1127$.

82. See UNFAIR COMPETITION RESTATEMENT, supra note $4, \S 25 \mathrm{cmt}$. i.

83. The language of most state dilution statutes is drawn from the 1964 version of the Model State Trademark Bill. The dilution provisions in the 1992 version of the Model Bill correspond to those in the 1995 amendment to the Lanham Act, see 3 MCCARTHY, supra note $11, \S 22.04$, and thus may be narrower in scope than the prior model provision.

84. See UNFAIR COMPETITION RESTATEMENT, supra note $4, \S 25 \mathrm{cmt}$. e; 3 MCCARTHY, supra note $11, \S 24.17$. The report of the TRC noted that "[f]amous marks are most likely to be harmed by reduced distinctiveness." TRC Report, supra note 67, at 455.

85. See UNFAIR COMPETITION RESTATEMENT, supra note 4 , $\$ 25 \mathrm{cmt}$. g. 
promotion," "noncommercial use," and "news reporting and news commentary." 86 In virtually identical language, sponsors in the House and Senate promised that the bill would "not prohibit or threaten noncommercial expression, such as parody, satire, editorial and other forms of expression that are not a part of a commercial transaction." ${ }^{\text {} 77}$ Each of these statutory exceptions should be broadly construed.

"Fair use" is a term of art in trademark law. It refers to the nonconfusing use of a term, not as a trademark for the user's own goods, but instead for the purpose of communicating accurate information to prospective purchasers. For example, the long-standing fair use provision in section 33(b)(4) of the Lanham $\mathrm{Act}^{88}$ allows use of the original lexicographical meaning of a term that has become another's trademark for the purpose of fairly describing the user's own product. ${ }^{89}$ As an exception to federal dilution protection, "fair use" in comparative advertising should thus include any use that does not create confusion of source or otherwise misrepresent the characteristics of the user's goods or services. The TRC had warned that the dilution proposal "should not be used to discourage otherwise lawful comparative advertising." $"$ Further restrictions, such as those pursued in the Deere case, rely on tarnishment rather than dilution of distinctiveness and are thus beyond the literal language of the federal amendment. ${ }^{91}$

The exception for "noncommercial use" should similarly be interpreted in accordance with the broad assurances offered by the amendment's supporters. In particular, the fact that an expressive, nontrademark use of a mark appears on a product offered for sale in the marketplace should not exclude the use from protection. Most forms of expression are sold to the public, including most of the parodies, satires, and editorials referred to by the bill's sponsors on the floors of Congress. When the product that buyers are buying is the expression conveyed through the use of a mark, the use should not be deemed "commercial." The parody of the Michelob advertisement in Anheuser-Busch should be

86. 15 U.S.C.A. $\S 1125(c)(4)$ (West Supp. 1996).

87. 141 Cong. Rec. S19310 (daily ed. Dec. 29, 1995) (statement of Sen. Hatch); id. at H14318 (daily ed. Dec. 12, 1995) (statement of Rep. Moorhead). See also the assurances given by Senator Leahy: "I continue to believe, as our House colleagues also affirm, that parody, satire, editorial, and other forms of expression will remain unaffected by this legislation." Id. at S19312 (daily ed. Dec. 29, 1995) (statement of Sen. Leahy). Senator Leahy also expressed the hope "that this antidilution statute can help stem the use of deceptive Internet addresses taken by those who are choosing marks that are associated with the products and reputations of others." Id. Application of the antidilution amendment against a defendant who uses a well-known mark to identify a site on the Internet is entirely consistent with an interpretation limiting the amendments's scope to unauthorized use as a trade or service mark. See Hasbro, Inc. v. Internet Entertainment Group, Ltd., 40 U.S.P.Q.2d 1479, 1996 WL 84853 (W.D. Wash. 1996) (preliminary injunction issued under the antidilution amendment against a defendant who used the plaintiff's mark "to identify a sexually explicit Internet site").

88. 15 U.S.C.A. \& 1115(b)(4) (West Supp. 1996).

89. See also UNFAIR COMPETITION RESTATEMENT, supra note 4, § 28.

90. TRC Report, supra note 67 , at 462.

91. In Hormel Foods Corp. v. Jim Henson Prods., 73 F.3d 497, 507 (2d Cir. 1996), the Second Circuit said that its decision in Deere was "a recognition of a broad view of tarnishment, where that doctrine had been sometimes narrowly confined." 
beyond the reach of the federal dilution act, whether the expression appears in a magazine, on a poster, or on the front of a $t$-shirt.

\section{IV \\ CONCLUSION}

Trademark legislation will increasingly be shaped by the pressures of international commerce. As the Lanham Act ventures further from the security of the common law, the responsibility for ensuring a reasonable balance between private rights and public access will fall more heavily on the courts.

Section 43(c) of the Lanham Act should be limited to the use of a famous mark as a trademark for the user's own product. Allowing a few questionable parodies or off-color $t$-shirts and some overly aggressive comparative advertisements is a small price for maintaining access to symbols that have become such important ingredients in our public dialogue. 